\title{
Photosynthetic performance, DNA damage and repair in gametes of the endemic Antarctic brown alga Ascoseira mirabilis exposed to ultraviolet radiation
}

\author{
MICHAEL Y. ROLEDA, ${ }^{1,2 \star}$ KATHARINA ZACHER,${ }^{3}$ ANGELA WULFF, ${ }^{4}$ \\ DIETER HANELT ${ }^{5}$ AND CHRISTIAN WIENCKE ${ }^{3}$ \\ ${ }^{1}$ Biologische Anstalt Helgoland, Alfred Wegener Institute for Polar and Marine Research, Marine \\ Station, Helgoland, ${ }^{2}$ Institute for Polar Ecology, University of Kiel, Wischhofstr. 1-3, Bldg. 12, 24148 \\ Kiel, Germany (Email: mroleda@ipoe.uni-kiel.de), ${ }^{3}$ Alfred Wegener Institute for Polar and Marine \\ Research, Section Seaweed Biology, Bremerhaven, ${ }^{5}$ Biozentrum Klein Flottbek, University of Hamburg, \\ Hamburg, Germany; and ${ }^{4}$ Department of Marine Ecology, Marine Botany, Göteborg University, \\ Göteborg, Sweden
}

\begin{abstract}
Stress physiology on the reproductive cells of Antarctic macroalgae remained unstudied. Ascoseira mirabilis is endemic to the Antarctic region, an isolated ecosystem exposed to extreme environmental conditions. Moreover, stratospheric ozone depletion leads to increasing ultraviolet radiation $(280-400 \mathrm{~nm})$ at the earth's surface, thus it is necessary to investigate the capacity of reproductive cells to cope with different UV irradiances. This study is aimed to investigate the impact of exposure to different spectral irradiance on the photosynthetic performance, DNA damage and gamete morphology of the $A$. mirabilis. Gametangia, gametes and zygotes of the upper sublittoral brown alga $A$. mirabilis were exposed to photosynthetically active radiation ( $\mathrm{PAR}=\mathrm{P} ; 400$ $700 \mathrm{~nm}$ ), P + UV-A radiation (UV-A, 320-400 nm) and P + UV-A + UV-B radiation (UV-B, 280-320 nm). Rapid photosynthesis versus irradiance curves of freshly released propagules were measured. Photosynthetic efficiencies and DNA damage (in terms of cyclobutane pyrimidine dimers) were determined after 1,2, 4 and $8 \mathrm{~h}$ exposure as well as after 2 days of recovery in dim white light. Saturation irradiance $\left(I_{\mathrm{k}}\right)$ in freshly released propagules was $52 \mu \mathrm{mol}$ photons $\mathrm{m}^{-2} \mathrm{~s}^{-1}$. Exposure for $1 \mathrm{~h}$ under $22 \mu \mathrm{mol}$ photons $\mathrm{m}^{-2} \mathrm{~s}^{-1}$ of PAR significantly reduced the optimum quantum yield $\left(F_{\mathrm{v}} / F_{\mathrm{m}}\right)$, suggesting that propagules are low light adapted. Furthermore, UVR significantly contributed to the photoinhibition of photosynthesis. Increasing dose as a function of exposure time additionally exacerbated the effects of different light treatments. The amount of DNA damage increased with the UV-B dose but an efficient repair mechanism was observed in gametes pre-exposed to a dose lower than $5.8 \times 10^{3} \mathrm{~J} \mathrm{~m}^{-2}$ of UV-B. The results of this study demonstrate the negative impact of UV-B radiation. However, gametes of $A$. mirabilis are capable of photosynthetic recovery and DNA repair when the stress factor is removed. This capacity was observed to be dependent on the fitness of the parental sporophyte.
\end{abstract}

Key words: Ascoseira mirabilis, cyclobutane pyrimidine dimer, optimum quantum yield, photosynthetic recovery, P-I curve.

\section{INTRODUCTION}

Ascoseira mirabilis Skottsberg is a perennial brown macroalga endemic to the Antarctic region. The high level of endemism in Antarctica is attributed to the surrounding deep ocean basins, the circumpolar current and the Polar Frontal Zone that have isolated the continent and its organisms for approximately 30 million years (Peck et al. 2006). During that time, atmospheric oxygen $\left(\mathrm{O}_{2}\right)$ and therefore, stratospheric

${ }^{\star}$ Corresponding author.

Accepted for publication February 2007. ozone $\left(\mathrm{O}_{3}\right)$ were probably lower than at present exposing the earth to very high doses of ultraviolet radiation (UVR, Rozema et al. 1997). Marine macroalgae have also been subjected to higher mean sea surface temperatures over most of their evolutionary history, than prevailing today (Raven et al. 2002). The lowering of sea surface temperatures at southern high latitudes occurred during the late Miocene (Crame 1993). The capacity of Antarctic macroalgae to adapt to ice, low temperatures, and seasonal light fluctuations is an important determinant of their biological fitness.

The marine benthic flora of Antarctica is predominantly sublittoral. Higher number of species and dense 
macroalgal assemblages occur at depths in the sublittoral called the 'bare zone' while the eulittoral flora is less well developed where inconspicuous algae occur only on short stretches of rocky coastline that remain ice-free for a few months in summer (Clayton 1994). Ascoseira mirabilis grows in the upper subtidal zone (Klöser et al. 1996; Quartino et al. 2005) while other large brown algae of the order Desmarestiales grow most abundantly at greater depths (Wiencke et al. 2007).

The $A$. mirabilis thallus is diploid and monoecious. Sexual reproduction is isogamous. Conceptacles are scattered all over the blades containing chains of gametangia surrounding a central hair. Gametangia are eight-chambered and following the segregation of a vestigial nucleus, each chamber releases one gamete (Clayton 1987; Müller et al. 1990). Gametes are heterokont and zygote formation follows immediately after fusion of gametes.

Advances in Antarctic macroalgal research are constrained by logistics. Aside from studies on the life history of Ascoseira, only limited studies on its anatomy (Clayton \& Ashburner 1990) and basic physiology (Gómez et al. 1995a,b, 1996) are available. Concern about global environmental changes, especially the increase in UV-B radiation due to ozone depletion, makes it necessary to study stress physiology on primary producers. In Antarctica, research efforts to evaluate the impact of this phenomenon have mostly focused on phytoplankton (Meador et al. 2002; Nunez et al. 2006). However, phytoplankton does not represent the only significant photoautotroph component of the aquatic environment susceptible to elevated UV-B. Reviews on Antarctic macroalgal research show the lack of information on the effect of UVR on seaweeds (Wiencke 1996; Wiencke et al. 2007). This is in contrast to Arctic species where recent studies have shown that early life stages of macroalgae are most sensitive to UVR and their sensitivity is related to the depth distribution pattern of the adult sporophytes (Roleda et al. 2006a; Wiencke et al. 2006).

Total ozone varies strongly with latitude over the globe, with highest concentration in middle and high latitudes. Before the stratosphere at polar latitudes was affected by anthropogenic chlorine and bromine, the naturally occurring spring time ozone levels over Antarctica were about $25 \%$ lower than spring time ozone levels over the Arctic (Fahey 2003). This natural difference between Antarctic and Arctic conditions exists due to the exceptionally low temperatures and different winter wind patterns within the Antarctic stratosphere as compared with the Arctic. Since the detection of stratospheric ozone depletion over Antarctica in the early 1980s, a yearly net spring time loss of $60-70 \%$ has been a recurring phenomenon that intensifies ambient UV-B radiation on the biosphere (Crutzen 1992; Herman et al. 1996).
Moreover, the area affected by ozone depletion has expanded to fivefold over the past decades in continental Antarctica. The negative impact of exposure to UVR on reproductive cells of macroalgae includes (i) inhibition of photosynthesis and eventual photodamage to the photosynthetic apparatus (Roleda et al. 2006a); (ii) damage to microtubules causing inhibition of nuclear division (Huovinen et al. 2000); (iii) formation of cyclobutane pyrimidine dimers (CPDs) in the DNA (Roleda et al. 2004, 2005, 2006b); and (iv) production of reactive oxygen species responsible for oxidative damage within the cell (Rijstenbil et al. 2000).

To our knowledge, no physiological study has been carried out on the effects of UVR on the reproductive cells of Antarctic macroalgae, which are the life history stage considered to be most susceptible to environmental stress. This study is aimed to investigate the impact of exposure to different spectral irradiance on the photosynthetic performance, DNA damage and gamete morphology of $A$. mirabilis. We further investigated the capacity of gametes to recover and repair UVR-induced damage when UVR stress was removed. The present study is of interest because it is the first demonstration of the deleterious effect of enhanced UV-B radiation due to stratospheric ozone depletion on the gametes of endemic Antarctic macroalgae.

\section{MATERIALS AND METHOD}

\section{Algal material}

Fertile sporophytes of $A$. mirabilis were collected in October 2004 during low tide in the upper sublittoral flat of Peñón Uno, King George Island (Antarctica, $62^{\circ} 14.82^{\prime} \mathrm{S}, 58^{\circ} 41.05^{\prime} \mathrm{W}$ ). Mature blades with conceptacles containing gametangia were excised from five different sporophytes, cleaned of epiphytes, blotted with tissue paper and kept in darkness in a moist chamber at $0^{\circ} \mathrm{C}$ overnight. Blades were then immersed in $5-10 \mathrm{~mL}$ filtered $(0.2 \mu \mathrm{m}$ pore size $)$ seawater at $2 \pm 1.5^{\circ} \mathrm{C}$ and exposed to light $(10 \mu \mathrm{mol}$ photons $\mathrm{m}^{-2} \mathrm{~s}^{-1}$ ) to induce release of the reproductive cells. Freshly released gametangia were maintained under low-light condition (1-2 $\mu \mathrm{mol}$ photons $\left.\mathrm{m}^{-2} \mathrm{~s}^{-1}\right)$. The initial gametangium density was counted by use of a Sedgewick-Rafter Cell S50 spore counter (Graticules Ltd, Tonbridge, England). Stock suspensions were diluted with filtered seawater to give densities between $3 \times 10^{3}$ and $4 \times 10^{3}$ gametangia $\mathrm{mL}^{-1}$ among the five replicates. During the course of the experiments, gametes were released and zygotes were formed. 


\section{Irradiation treatments}

Photosynthetically active radiation (PAR) was provided by white fluorescent tubes (Osram, L65 Watt/ 25S, Munich, Germany). UVR was generated by UV-A-340 fluorescent tubes (Q-Panel, Cleveland, $\mathrm{OH}, \mathrm{USA})$. Cell culture dishes were covered with one of the following filters to cut off different wavelength ranges from the spectrum emitted by the fluorescent tubes: Ultraphan transparent (Digefra $\mathrm{GmbH}$, Germany), Folanorm (Folex GmbH, Germany) or Ultraphan URUV farblos corresponding to the PAR + UV-A + UV-B (PAB), PAR + UV-A (PA) and PAR (P) treatments, respectively. UVR was measured using a Solar Light PMA 2100 radiometer equipped with the UV-A sensor PMA 2110 and the UV-B Sensor PMA 2106 (Solar light, Philadelphia, USA). UVR below the UV-transparent filter was $4.34 \mathrm{~W} \mathrm{~m}^{-2}$ UV-A and $0.40 \mathrm{~W} \mathrm{~m}^{-2}$ UV-B. PAR was measured using a cosine quantum sensor attached to a LI-COR data logger (LI-1000, LI-COR Biosciences, Lincoln, Nebraska, USA) to be $22 \mu \mathrm{mol}$ photons $\mathrm{m}^{-2} \mathrm{~s}^{-1}$ (approx. $4.73 \mathrm{~W} \mathrm{~m}^{-2}$ ).

\section{Light microscopy}

The structure of released reproductive cells was observed by light microscopy (Zeiss Axiolab, Germany). Structural changes after exposure to different light treatments and 2 days post cultivation in low white light were documented. Microscopic pictures were taken with a digital camera (Canon PowerShot A80, Switzerland).

\section{Chlorophyll fluorescence measurements}

Photosynthetic efficiency was measured as variable fluorescence of photosystem II (PSII) using a Water Pulse Amplitude Modulation fluorometer (WaterPAM) consisting of Emitter-Detector Unit Water-ED and PAM-Control Universal Control Unit connected to a PC operated with WinControl software (Heinz Walz GmbH, Effeltrich, Germany). Immediately after adjustment of gametangium density, the gametangium suspension was filled into $5 \mathrm{~mL}$ Quartz cuvettes and the maximum quantum yield $\left(F_{\mathrm{v}} / F_{\mathrm{m}}\right)$ was measured inside the Emitter-Detector Unit at time zero $(n=5)$. After 3 min dark incubation, $F_{0}$ was measured with a red measuring light pulse (approx. $0.3 \mu \mathrm{mol}$ photons $\mathrm{m}^{-2} \mathrm{~s}^{-1}, 650 \mathrm{~nm}$ ), and $F_{\mathrm{m}}$ was determined with a $600 \mathrm{~ms}$ completely saturating white light pulse (approx. $275 \mu \mathrm{mol}$ photons $\mathrm{m}^{-2} \mathrm{~s}^{-1}$ ). Photosynthesis (in terms of relative electron transport rate, $\mathrm{rETR}=$ $\left.\mathrm{PFR} \times \Delta F / F^{\prime}{ }_{\mathrm{m}}\right)$ versus irradiance curve (P-I curve) was measured two times in every replicate of the time zero control (using fresh suspension every measurement; $n=3$, chosen at random from the five replicates) using low and high actinic light intensities making up 10 points $(17,26,38,58,87,128,198,294,419$, $585 \mu \mathrm{mol}$ photons $\mathrm{m}^{-2} \mathrm{~s}^{-1}$ ). The hyperbolic tangent model of Jassby and Platt (1976) was used to estimate P-I curve parameters described as:

$$
\mathrm{rETR}=\mathrm{rETR}_{\max } \times \tanh \left(\alpha \times I_{\mathrm{PAR}} \times \mathrm{rETR}_{\max }{ }^{-1}\right)
$$

where $\mathrm{rETR}_{\max }$ is the maximum relative electron transport rate, tanh is the hyperbolic tangent function, $\alpha$ is the electron transport efficiency and $I$ is the photon fluence rate of PAR. The saturation irradiance for electron transport $\left(I_{\mathrm{k}}\right)$ was calculated as the light intensity at which the initial slope of the curve $(\alpha)$ intercepts the horizontal asymptote $\left(\mathrm{rETR}_{\max }\right)$. Curve fit was calculated with the Solver Module of MS-Excel using the least squares method comparing differences between measured and calculated data.

Controls measured at time zero were filled into corresponding culture dishes $(35 \mathrm{~mm} \times 10 \mathrm{~mm}$; CorningTM, Corning Inc., NY, USA). To evaluate the effect of different radiation treatments (three levels: $P$, $\mathrm{PA}$ and $\mathrm{PAB}$ ) and exposure times (four levels: 1, 2, 4 and $8 \mathrm{~h}$ ), samples of fresh gametangium suspension (not exceeding $1 \mathrm{~h}$ after release) were filled into each culture dish (total experimental units $=60$ ). Samples corresponding to the five replicates were exposed to each treatment combination of radiation and exposure time at $2 \pm 1.5^{\circ} \mathrm{C}$. After treatments, $F_{\mathrm{v}} / F_{\mathrm{m}}$ was determined and the suspension was returned to the same culture dish and cultivated under dim white light $\left(4 \pm 1 \mu \mathrm{mol}\right.$ photons $\left.\mathrm{m}^{-2} \mathrm{~s}^{-1}\right)$ at the same temperature for recovery. Time zero control was also maintained at the same condition. Measurements of photosynthetic recovery were made after $48 \mathrm{~h}$ in dim white light condition. Settled and germinating zygotes were slowly resuspended by sucking and jetting the medium against the bottom of the culture dish using Eppendorf pipettes.

\section{DNA damage and repair}

DNA damage and its subsequent repair were determined after exposure to the whole light spectrum at different exposure times of $1,2,4$, and $8 \mathrm{~h}$. From the gametangia suspension $\left(3 \times 10^{3}-4 \times 10^{3} \mathrm{~mL}^{-1}\right)$, $40 \mathrm{~mL}$ was used for each experimental unit. For each treatment, six experimental units were prepared. After the irradiation treatment, three experimental units (as replicates) were processed immediately while the other three were allowed to recover for 2 days in low white light $\left(4 \pm 1 \mu \mathrm{mol}\right.$ photons $\left.\mathrm{m}^{-2} \mathrm{~s}^{-1}\right)$ before processing. Reproductive cells were resuspended from the bottom of the Petri dishes by jetting pressurized seawater from 
a wash bottle. The suspensions were filtered through $44 \mathrm{~mm}$ diameter $1.0 \mu \mathrm{m}$ pore size Nuclepore polycarbonate membrane (Whatman, UK). Filters were individually put into $2 \mathrm{~mL}$ Eppendorf tubes and frozen at $-80^{\circ} \mathrm{C}$. DNA was extracted using $2 \%$ CTAB extraction buffer and quantified fluorometrically using the PicoGreen assay (Molecular Probes, Eugene, OR) and a Cary Eclipse Fluorescence Spectrophotometer (Variance Scientific Instrument, CA) (Roleda et al. 2004). The accumulation of CPDs was determined following a two-step antibody assay using antithymine dimer H3 (Affitech, Oslo, Norway) and rabbit antimouse immunoglobulins (conjugated with horseradish peroxidase, DakoCytomation, Glostrup, Denmark). Chemiluminescent detection was subsequently done using ECL Western blotting detection reagent (Amersham Buckinghamshire, UK) (Roleda et al. 2005). Developed films (using X-ray film developer) were scanned using Biorad imaging densitometer (Model GS-700, Bio-Rad Laboratories, USA) and grey scale values were quantified using Multi-Analyst (Macintosh Software for Bio-Rad's Image Analysis Systems). A calibration series of UV-irradiated calf thymus DNA (Serva) supplemented with unexposed DNA was included giving $1 \mu \mathrm{g} / \mathrm{mL}$ DNA for each calibration point. The UV-irradiated DNA (45 min exposure to 2 TL $20 \mathrm{~W} / 12$ lamps, Philips, Eindhoven, Netherlands) was previously calibrated against UV-irradiated Hela DNA with known amounts of CPDs (kindly provided by A. Vink). CPDs were quantified by comparing the grey scales within the linear range of the film.

\section{Statistical analysis}

Data were tested for homogeneity (Levene Statistics) of variance. Corresponding transformations were made to heteroskedastic data. Photosynthetic response of each sporophyte (as random variable) to varying irradiance, exposure time (as fixed variables) and their interaction effect were tested using analyses of covariance (ANCOVA, $P<0.05$ ). When an interaction effect was observed, significant difference between subgroups was determined using post hoc multiple comparison test. DNA damage and repair were tested using one-way analysis of variance (ANOva, $P<0.05$ ), followed by Duncan's multiple range test $(P<0.05)$. Statistical analyses were made using SPSS software (Chicago, IL, USA).

\section{RESULTS}

Upon immersion of a fertile thallus in seawater, masses of gametangia (8-10 $\mu \mathrm{m}$ length) were released through the ostioles of the conceptacles (Fig. 1a).
Each gametangium contains eight gametes (2.5-3 $0 \mu \mathrm{m}$, Fig. 1b). Gamete release and fertilization were observed in all light treatments but retarded in PAB treatments. Under highest exposure time of $8 \mathrm{~h} \mathrm{PAB}$, $80-90 \%$ of the viable gametes remained inside the gametangium (Fig. 1f).

The steep initial slope, alpha $\left(\alpha=0.095, R^{2}=0.98\right)$, in the photosynthesis-irradiance curve of freshly released gametes showed efficient use of photon fluence in the reproductive cells of Ascoseira. A minimal relative electron transport rate $\left(\mathrm{rETR}_{\max }=5\right)$ was observed and photosynthesis was saturated already at $52 \mu \mathrm{mol}$ photons $\mathrm{m}^{-2} \mathrm{~s}^{-1}$ of actinic light. The $\mathrm{rETR}_{\max }$ of Ascoseira was already photoinhibited above $300 \mu \mathrm{mol}$ photons $\mathrm{m}^{-2} \mathrm{~s}^{-1}$ (Fig. 2).

Initial mean optimum quantum yield $\left(F_{\mathrm{v}} / F_{\mathrm{m}}\right)$ of low light adapted gametes was $0.400 \pm 0.06$. Exposure to $1 \mathrm{~h}$ of $22 \mu \mathrm{mol}$ photons $\mathrm{m}^{-2} \mathrm{~s}^{-1}$ of PAR decreased the $F_{\mathrm{v}} / F_{\mathrm{m}}$ by $62 \%$. Additional $20 \%$ and $25 \%$ reduction in $F_{\mathrm{v}} / F_{\mathrm{m}}$ was observed when light was supplemented with UV-A and UV-A + UV-B, respectively (Fig. 3a). Increasing exposure time to 2,4 and $8 \mathrm{~h}$ further resulted in a decrease of the $F_{\mathrm{v}} / F_{\mathrm{m}}$ in all treatments indicating that propagules are low light adapted and susceptible to UVR.

After post cultivation for 2 days in dim white light, the $F_{\mathrm{v}} / F_{\mathrm{m}}$ of untreated gametes $(0.446 \pm 0.05)$ increased slightly. An efficient recovery was observed under all light and exposure time treatments (Fig. 3b). Photosynthetic recovery was, however, found to be dependent on the fitness of the parental sporophyte (Table 1). Optimum quantum yields of propagules obtained from Plant 1 in all treatments, except $8 \mathrm{~h}$ pre-exposure to $\mathrm{PA}$ and $\mathrm{PAB}$, recovered to the control value (Table 1). Propagules obtained from two sporophytes (designated as plants 2 and 3) were moderately fit. Photosynthetic efficiency of propagules in the other two sporophytes (plants 4 and 5) did not fully recover after pre-exposure to treatments longer than $2 \mathrm{~h}$ PA and $1 \mathrm{~h} \mathrm{PAB}$ equivalent to doses higher than $6.8 \times$ $10^{4} \mathrm{~J} \mathrm{~m}^{-2}$ of PAR, $3.1 \times 10^{4} \mathrm{~J} \mathrm{~m}^{-2}$ of UV-A and $1.4 \times$ $10^{3} \mathrm{~J} \mathrm{~m}^{-2}$ of UV-B. Analysis of covariance (ANCOVA, $P<0.01$ ) showed that gametes obtained from individual sporophytes exclusively differ in their response to different treatments. Significant effects of spectral irradiance and exposure time were also observed in the optimum quantum yields of propagules after treatment exposure and after recovery (Table 2). A significant interactive effect between irradiance and exposure time was observed in the $F_{\mathrm{v}} / F_{\mathrm{m}}$ of propagules after exposure but not after recovery. Post hoc multiple comparison test showed several significantly different subgroups in $F_{\mathrm{v}} / F_{\mathrm{m}}$ after exposure treatment. Groups ranking showed that photosynthetic efficiency was lowest in $8 \mathrm{~h}$ PAB followed by a subgroup consisting of 2, 4 and $8 \mathrm{~h}$ PA and 2 and $4 \mathrm{~h} \mathrm{PAB}$. Photosynthetic efficiency was highest in the subgroup consisting of 1 


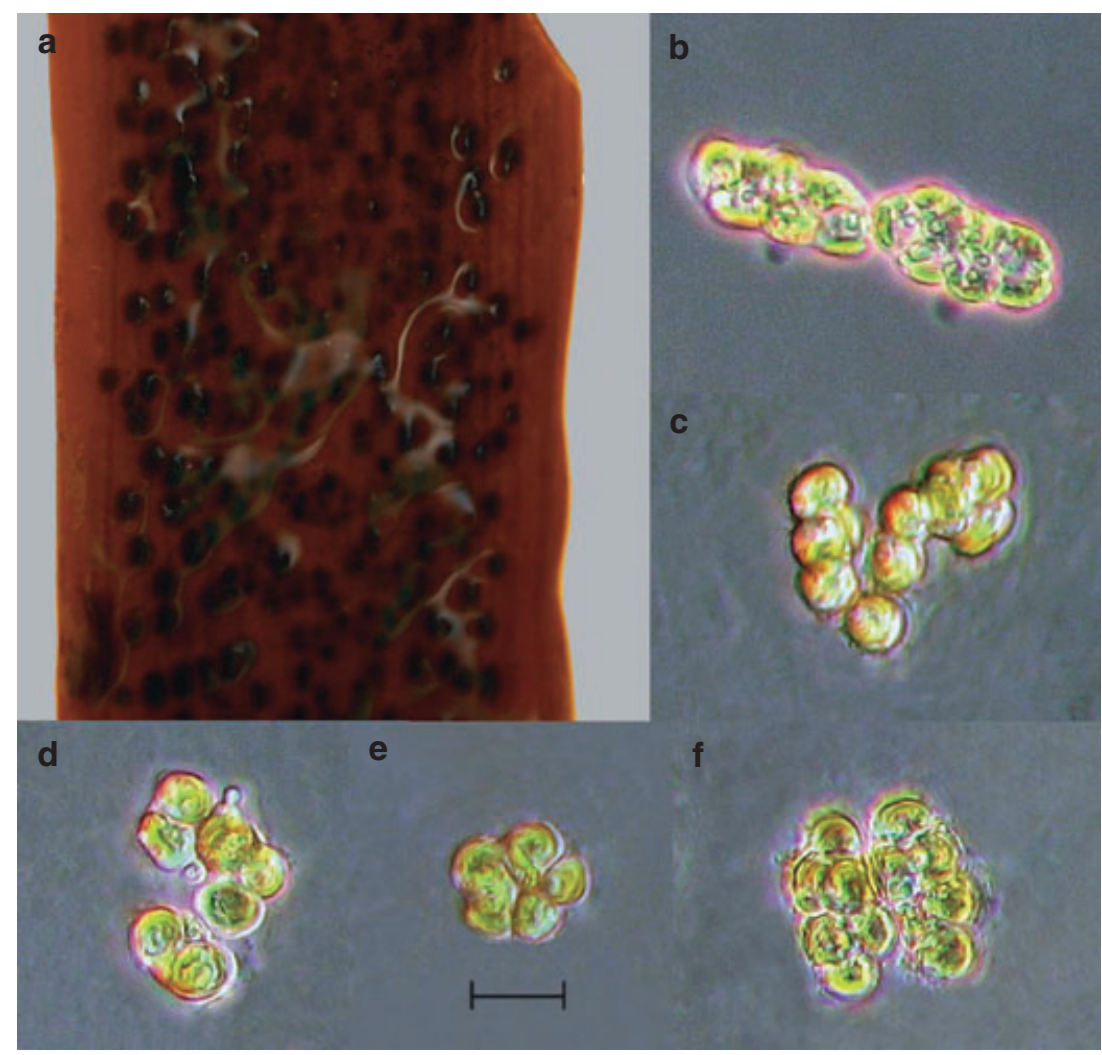

Fig. 1. Ascoseira mirabilis sporophyte with conceptacles containing gametangia (a), releasing masses of gametangia containing eight gametes (b) upon re-immersion in seawater. Gamete release and syngamy were observed in controls (c) and in $8 \mathrm{~h} P-$ and PA-exposed gametangial suspensions ( $\mathrm{d}$ and e, respectively).Viable gametes remained inside the gametangial complex among $8 \mathrm{~h}$ PAB-exposed samples (f). Micrographs (scale $=5 \mu \mathrm{m}$ ) were taken after exposure treatments and 2 days recovery in low white light. $\mathrm{P}$, photosynthetically active radiation; PA, P + UV-A radiation; PAB, P + UV-A + UV-B radiation.

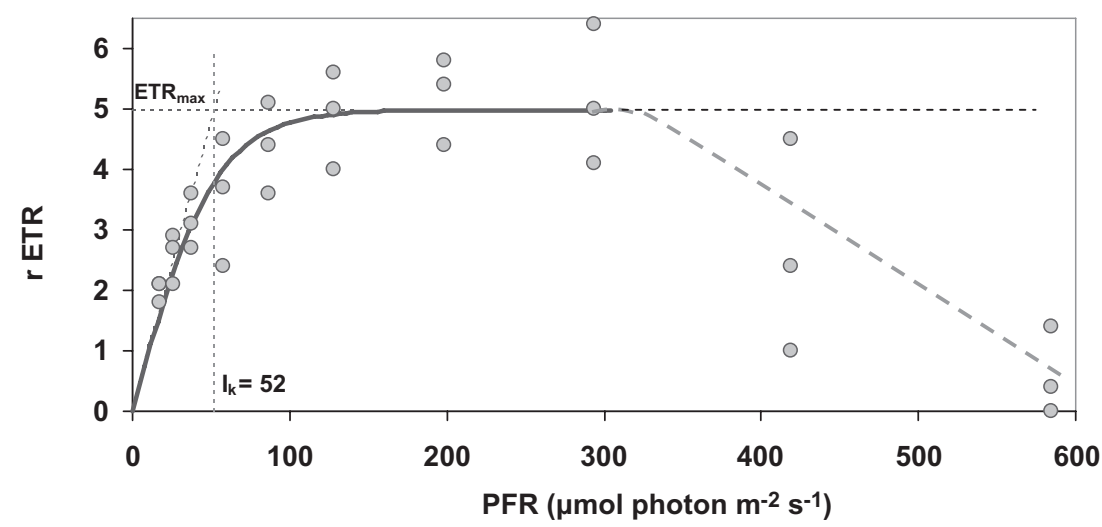

Fig. 2. Photosynthetic performance (P-I curve) of gametangial masses and gametes from Ascoseira mirabilis $(n=3)$ immediately after release from the conceptacle. PFR is the respective photon fluence rate of actinic white light and rETR is the relative transport rate. Saturating irradiance $\left(I_{\mathrm{k}}\right)$ is estimated as the point at which the initial slope $\left(\alpha=0.095, R^{2}=0.98\right)$ crosses the maximum photosynthesis $\left(\mathrm{rETR}_{\max }\right)$ using a hyperbolic tangent model. P-I curve, photosynthesis versus irradiance curve.

and $2 \mathrm{~h} \mathrm{P}$ treatment, and followed by the subgroup consisting of $1 \mathrm{~h} \mathrm{PA}, 1 \mathrm{~h} \mathrm{PAB}$, and 4 and $8 \mathrm{~h} \mathrm{P}$ treatments.

Formation of CPDs was observed in propagules after $1 \mathrm{~h}$ exposure to PAB treatment. DNA damage increased with increasing UV-B dose to a maximum of $37.55 \pm 2.3 \mathrm{CPD} \mathrm{Mb} \mathrm{Mb}^{-1}$ after $8 \mathrm{~h}$ exposure. Analysis of variance (ANOvA, $P<0.01$ ) showed significant effect of UV-B dose on CPD formation. Duncan's multiple range test $(P<0.05)$ revealed three different subsets 
(Fig. 4). Effective DNA repair was found after 2 days post cultivation in low white light. No detectable CPD was observed in gametes pre-exposed to dose lower than $5.8 \times 10^{3} \mathrm{~J} \mathrm{~m}^{-2}$ of UV-B. The remaining DNA damage in spores pre-exposed to higher UV-B dose was minimal $\left(0.84-2.32 \mathrm{CPD} \mathrm{Mb}^{-1}\right)$.

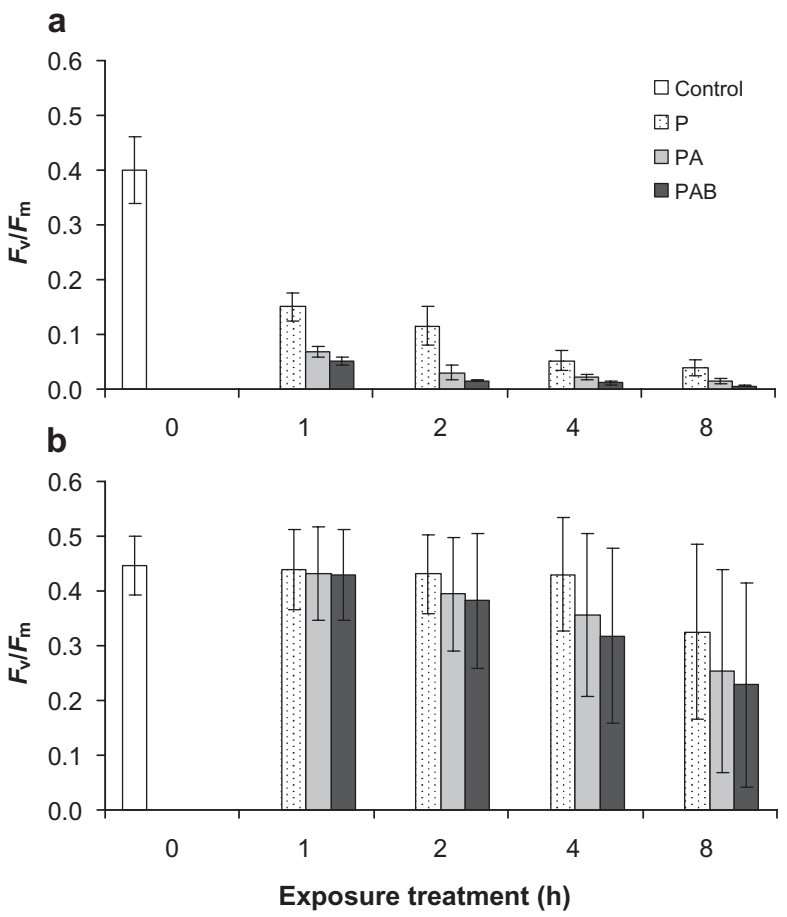

Fig. 3. Mean optimum quantum yield $\left(F_{\mathrm{v}} / F_{\mathrm{m}}\right)$ of propagules (gametangia, gametes and zygotes) during treatment (a) of photosynthetically active radiation $=\mathrm{P} ; \mathrm{P}+\mathrm{UV}-\mathrm{A}=$ $\mathrm{PA} ; \mathrm{PA}+\mathrm{UV}-\mathrm{B}=\mathrm{PAB}$ and exposure time. Corresponding photosynthetic recovery (b) after $48 \mathrm{~h}$ post culture in low white light $\left(4 \mu \mathrm{mol}\right.$ photons $\left.\mathrm{m}^{-2} \mathrm{~s}^{-1}\right)$. Control $(=0)$ is without treatment and continuously maintained at $4 \mu \mathrm{mol}$ photons $\mathrm{m}^{-2} \mathrm{~s}^{-1}$. Vertical bars are standard deviations, $n=5$. Corresponding statistical analysis is presented in Table 2.

\section{DISCUSSION}

This study shows for the first time the UVR sensitivity of the reproductive cells of an endemic Antarctic macroalga. Propagules of $A$. mirabilis are low light adapted and strongly photoinhibited by PAR. UVR further contributes to the photoinhibition of photosynthesis. UV-B induces DNA damage but an effective repair mechanism is observed. The gametangium walls are assumed to offer UV protection to gametes inside the gametangia released from the conceptacles.

Ascoseira mirabilis is the only species in the order Ascoseirales. Its growth form is reminiscent of the Laminariales while its life history follows a fucalean pattern but sexual reproduction in this species is isogamous in contrast to the Fucales (Moe \& Henry 1982; Clayton 1987). In Laminariales, zoospores are directly liberated from the sorus. Release of whole sporangia is sometimes observed under unfavourable condition. In Ascoseirales, the extrusion of gametangial masses through the ostioles of their conceptacles precedes the release of gametes from the gametangia (Müller et al. 1990). The sustained release of gametes takes several hours until gametangia become empty. Under PAB treatment, however, most gametes were not released after 2 days from the gametangia. They were observed to remain enclosed inside the gametangium walls and looked healthy and bigger in size. Relative to $\mathrm{P}$ treatment, the retention of gametes inside the gametangium wall seems to be a reproductive strategy to protect sensitive cells from environmental stress. Whether viable gametes will be eventually released from the gametangia remains to be studied.

The $I_{\mathrm{k}}$ estimates $\left(52 \mu \mathrm{mol}\right.$ photons $\left.\mathrm{m}^{-2} \mathrm{~s}^{-1}\right)$ derived from $\mathrm{rETR}_{\max }$ as minimum saturating irradiance was higher than temperate $\left(20-40 \mu \mathrm{mol}\right.$ photons $\left.\mathrm{m}^{-2} \mathrm{~s}^{-1}\right)$ and Arctic $\left(13-18 \mu \mathrm{mol}\right.$ photons $\left.\mathrm{m}^{-2} \mathrm{~s}^{-1}\right)$ Laminariales

Table 1. Individual sporophyte-specific vitality in Ascoseira mirabilis impacts the photosynthetic recovery (optimum quantum yield, $\left.F_{\mathrm{v}} / F_{\mathrm{m}}\right)$ of their respective reproductive cells after exposure to different spectral irradiance

\begin{tabular}{|c|c|c|c|c|c|c|c|c|c|c|c|c|}
\hline \multirow{3}{*}{$\begin{array}{l}\text { Source } \\
\text { plant }\end{array}$} & \multicolumn{12}{|c|}{ Exposure treatments (h) } \\
\hline & \multicolumn{4}{|c|}{ PAR } & \multicolumn{4}{|c|}{ PAR + UV-A } & \multicolumn{4}{|c|}{$\mathrm{PAR}+\mathrm{UV}-\mathrm{A}+\mathrm{UV}-\mathrm{B}$} \\
\hline & 1 & 2 & 4 & 8 & 1 & 2 & 4 & 8 & 1 & 2 & 4 & 8 \\
\hline 1 & 0.558 & 0.536 & 0.559 & 0.521 & 0.549 & 0.542 & 0.533 & 0.487 & 0.542 & 0.534 & 0.519 & 0.461 \\
\hline 2 & 0.459 & 0.468 & 0.459 & 0.411 & 0.481 & 0.442 & 0.426 & 0.353 & 0.476 & 0.451 & 0.400 & 0.320 \\
\hline 3 & 0.405 & 0.411 & 0.481 & 0.374 & 0.428 & 0.395 & 0.418 & 0.295 & 0.426 & 0.413 & 0.361 & 0.290 \\
\hline 4 & 0.378 & 0.354 & 0.246 & 0.152 & 0.337 & 0.285 & 0.204 & 0.073 & 0.334 & 0.246 & 0.157 & 0.040 \\
\hline 5 & 0.394 & 0.387 & 0.266 & 0.170 & 0.368 & 0.309 & 0.197 & 0.058 & 0.367 & 0.266 & 0.152 & 0.034 \\
\hline
\end{tabular}

Gametes were released from five individual sporophytes designated as source plant. Photosynthetic recovery of gametes and embryos were initiated in dim white light of $4 \mu \mathrm{mol}$ photons $\mathrm{m}^{-2} \mathrm{~s}^{-1}$ after treatment. Mean of untreated control after $48 \mathrm{~h}$ post cultivation is $0.446 \pm 0.054$. Optimum quantum yield $\left(F_{\mathrm{v}} / F_{\mathrm{m}}\right)$ of gametes, $48 \mathrm{~h}$ recovery after exposure. PAR, photosynthetically active radiation. 
Table 2. Analysis of covariance and significance values for the photosynthetic efficiency of Ascoseira mirabilis gametes exposed to different irradiance treatments and after recovery

\begin{tabular}{|c|c|c|c|c|c|}
\hline \multirow{2}{*}{$\begin{array}{l}\text { Dependent } \\
\text { variables }\end{array}$} & \multicolumn{2}{|c|}{ Independent variables } & \multirow[b]{2}{*}{ d.f. } & \multirow[b]{2}{*}{$F$-value } & \multirow[b]{2}{*}{$P$-value } \\
\hline & Covariate & Fixed factors & & & \\
\hline$F_{\mathrm{v}} / F_{\mathrm{m}}$ & Sporophyte & & 1 & 6.858 & $0.012^{\star}$ \\
\hline \multirow[t]{3}{*}{ After exposure } & & Spectral irradiance (A) & 2 & 188.091 & $<0.001^{\star}$ \\
\hline & & Exposure time (B) & 3 & 119.250 & $<0.001^{\star}$ \\
\hline & & $\mathrm{A} \times \mathrm{B}$ & 6 & 3.858 & $0.003^{\star}$ \\
\hline$F_{\mathrm{v}} / F_{\mathrm{m}}$ & Sporophyte & & 1 & 192.612 & $<0.001^{\star}$ \\
\hline \multirow{3}{*}{ After recovery } & & Spectral irradiance (A) & 2 & 6.994 & $0.002^{\star}$ \\
\hline & & Exposure time (B) & 3 & 22.334 & $<0.001^{\star}$ \\
\hline & & $\mathrm{A} \times \mathrm{B}$ & 6 & 0.846 & $0.541^{\mathrm{ns}}$ \\
\hline
\end{tabular}

^Significant; ns, not significant.

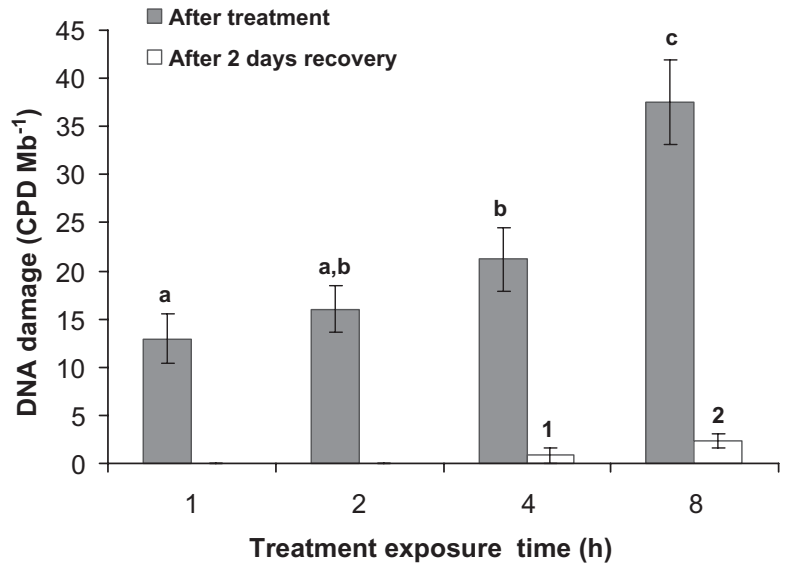

Fig. 4. UV-B-induced DNA damage (cyclobutane pyrimidine dimers per million nucleotides, $\mathrm{CPD} \mathrm{Mb}^{-1}$ ) in propagules of Ascoseira mirabilis after exposure to varying dose of UV-B radiation and remaining DNA damage after 2 days recovery in low white light $\left(4 \mu \mathrm{mol}\right.$ photons $\left.\mathrm{m}^{-2} \mathrm{~s}^{-1}\right)$. Vertical bars are standard deviations, $n=3$. Analysis of variance (ANOvA, $P<0.01$ ) shows significant difference between treatments. Letters and number on graph show result of Duncan multiple range's test $(P<0.05)$; different letters and numbers refer to significant differences between mean values.

(Roleda et al. 2005, 2006a) and comparable to subtropical/warm temperate $(41-77 \mu \mathrm{mol}$ photons $\mathrm{m}^{-2} \mathrm{~s}^{-1}$ ) kelp species (Amsler \& Neushul 1991). No study on P-I curve estimates on fucalean gametes or zygotes is available for comparison.

Differences in P, PA and PAB sensitivity of the optimum quantum yield in gametes were presumably caused by the degree of damage to PSII components or due to the xanthophyll cycle mediated down regulation of PSII (Gevaert et al. 2003). The interactive effects of radiation and exposure time treatments, however, showed that the measurable effects of different doses of PAR and UVR in the reduction of photosynthetic efficiency can be similar but the mechanisms behind PAR- and UVR-induced inhibition of photosynthesis are different (Franklin et al. 2003). Photosynthetic performance may be additionally depressed in light treatments supplemented with UVR by possible damage to the oxidizing site and reaction centre of PS II (Grzymski et al. 2001; Turcsányi \& Vass 2002). Part of the D1/D2 heterodimer, the major structural complex within PSII, can also be degraded by UV-B (Richter et al. 1990). Inactivation of the oxygen-evolving complex is moreover induced by blue light as well UV radiation while red light inactivates the photochemical reaction centre (Ohnishi et al. 2005). UV-A radiation, on the other hand, was found to be damaging for PSII by decreasing the electron flow from reaction centres to plastoquinone (Grzymski et al. 2001) affecting electron transport both at the water oxidizing complex and the binding site of the $\mathrm{Q}_{в}$ quinone electron acceptor (Turcsányi \& Vass 2002).

Exposure under comparable UV-B dose, induction and accumulation of UV-B-induced CPDs in $A$. mirabilis gametes were higher compared with zoospores of upper sublittoral kelp species from Helgoland (Laminaria digitata, Roleda et al. 2005) and Spitsbergen (Saccorhiza dermatodea, Roleda et al. 2006b). However, an efficient DNA damage repair mechanism was observed in gametes of $A$. mirabilis. The repair rate was relatively more efficient compared with the reproductive cells of Laminariales and Gigartinales species from the northern hemisphere (Roleda et al. 2004, 2005, 2006b). UV-B-induced DNA damage is generally repaired through photoreactivating light (van de Poll et al. 2002). Other repair mechanisms include nucleotide and base excision repair, and recombination repair (Roy 2000).

Impact of UVR can be counterbalanced by protection strategies such as avoidance, screening, photochemical quenching and repair (Vincent \& Neale 2000). The occurrence of phenolic compounds in 
reproductive cells of brown algae plays an important role in UV protection. In zoospores of Laminariales, increase in number and size of phlorotannincontaining physodes after exposure to UVR was invoked to contribute protection against cellular damage and enhanced germination rate (Wiencke et al. 2004). Induction of phlorotannin synthesis is, however, species specific and is not only inducible by UV-B radiation but also by PAR and UV-A (Roleda et al. 2006b,c). Mass released spores can screen each other serving as 'biofilter' and protect the lower layer of spores from excessive radiation (Roleda et al. 2006c).

Ascoseira mirabilis is endemic to Antarctica and has a distinct life history and reproductive biology apparently without any close affinities to any extant Phaeophyceae (Clayton 1987). In this species, gametes are enclosed in an extracellular sheath, the gametangium wall, which may function as UV-filter. Extracellular sheaths covering unicellular algae and cyanobacteria were found to contain scytonemin and sporopolleninlike material that offer protection against UV-C and UV-B radiation, respectively (Morrill \& Loeblich 1981; Dillon \& Castenholz 1999; Hagen et al. 2002). The UV-absorbing phlorotannins are common compounds in brown algal cell walls (Schoenwaelder \& Clayton 1999). Whether this compound is present in the gametangium wall remains to be studied. It may, if present, give some protection against UV radiation to the gametes.

Gametangial masses are first released from the conceptacle before the release of gametes, a strategy different from Laminariales where zoospores are immediately released from the sporangiumcontaining sorus when the environmental conditions are optimal. Furthermore, gametes of Ascoseira were retained inside the gametangium in PAB-treated samples compared with P-treated samples where syngamy followed immediately after gamete release. The Antarctic marine environment is characterized by extreme physical characteristics, such as low sea and air temperatures, annual extremes in light regime, wind speeds, disturbance and isolation (Peck et al. 2006) as well as naturally lower net spring time ozone levels (Fahey 2003). These environmental constraints might have exerted an evolutionary pressure to develop a unique life history and reproductive biology in A. mirabilis compared with other Phaeophyceae.

Despite the artificial laboratory irradiance in the absence of high PAR, UV irradiances comparable to that encountered in the field were observed to have a negative impact on the ecophysiology and biochemistry of $A$. mirabilis. Future study on the kinetics of photosynthetic recovery of reproductive cells (e.g. Roleda et al. 2006a) as well as the presence of UV-screening compounds (e.g. Wiencke et al. 2004;
Roleda et al. 2006c) and in situ germination capacity (e.g. Wiencke et al. 2006) could further enhance our understanding of the adaptive characteristics of this endemic Antarctic macroalga subjected to climate change due to depletion of stratospheric ozone layer and accumulation of greenhouse gases (Braathen 2005; GAW Report 165 2005). More studies on other Antarctic species with different zonation pattern are also necessary to determine how widespread the adaptive UV tolerance demonstrated here is.

\section{ACKNOWLEDGEMENTS}

This work was conducted under the agreement on scientific cooperation between the AWI and the Dirección Nacional del Antártico (DNA, Argentina) at Dallmann Laboratory, annex to Jubany station (King George Island, South Shetlands). We thank the German and Argentinean SCUBA divers for collecting fertile plant materials and the logistic team for support.

\section{REFERENCE}

Amsler C. D. \& Neushul M. (1991) Photosynthetic physiology and chemical composition of spores of the kelps Macrocystis pyrifera, Nereocystis luetkeana, Laminaria farlowii, and Pterygophora californica (Phaeophyceae). F. Phycol. 27, 26-34.

Braathen G. O. (2005) An Overview of the 2005 Antarctic Ozone Hole, Report 49 (WMO TD No. 1312). pp. 70.

Clayton M. N. (1987) Isogamy and a fucalean type of life history in the Antarctic brown alga Ascoseira mirabilis (Ascoseirales, Phaeophyceae). Bot. Mar. 30, 447-54.

Clayton M. N. (1994) Evolution of the Antarctic marine benthic algal flora. F. Phycol. 30, 897-904.

Clayton M. N. \& Ashburner C. M. (1990) The anatomy and ultrastructure of 'conducting channels' in Ascoseira mirabilis (Ascoseirales, Phaeophyceae). Bot. March 33, 63-70.

Crame J. A. (1993) Latitudinal range fluctuations in the marine realm through geological time. Trends Ecol. Evol. 3, 162-6.

Crutzen P. J. (1992) Ultraviolet on the increase. Nature 356, $104-5$.

Dillon J. G. \& Castenholz R. W. (1999) Scytonemin, a cyanobacterial sheath pigment, protects against UVC radiation: implication for early photosynthetic life. F. Phycol. 35, 67381.

Fahey D. W. (2003) Twenty Questions and Answers About the Ozone Layer: Scientific Assessment of Ozone Depletion: 2002. World Meteorological Organization, Geneva. [Reprinted from Scientific Assessment of Ozone Depletion: 2002, Global Ozone Research and Monitoring Project - Report No. 47, World Meteorological Organization, Geneva, 2003.]

Franklin L. A., Osmond C. B. \& Larkum A. W. D. (2003) Photoinhibition, UV-B and algal photosynthesis. In: Photosynthesis in Algae (eds A. W. Larkum, S. E. Douglas \& J. A. Raven) pp. 351-84. Kluwer Academic Publishers, Netherlands. 
GAW Report 165. Report of the CAS Working Group on Environmental Pollution and Atmospheric Chemistry and the GAW 2005 Workshop. WMO TD No. 1302, Genevea, Switzerland, 14-18 March 2005.

Gevaert F., Creach A., Davoult D. et al. (2003) Laminaria saccharina photosynthesis measured in situ: photoinhibition and xanthophylls cycle during a tidal cycle. Mar. Ecol. Prog. Ser. 247, 43-50.

Gómez I., Wiencke C. \& Weykam G. (1995a) Seasonal photosynthetic characteristics of Ascoseira mirabilis (Ascoseirales, Phaeophyceae) from King George Island, Antarctica. Mar. Biol. 123, 167-72.

Gómez I., Thomas D. N. \& Wiencke C. (1995b) Longitudinal profiles of growth, photosynthesis and light independent carbon fixation in the Antarctic brown alga Ascoseira mirabilis. Bot. Mar. 38, 157-64.

Gómez I., Wiencke C. \& Thomas D. N. (1996) Variations in photosynthetic characteristics of the Antarctic marine brown alga Ascoseira mirabilis in relation to thallus age and size. Eur. F. Phycol. 31, 167-72.

Grzymski J., Orrico C. \& Schofield O. M. (2001) Monochromatic ultraviolet light induced damage to Photosystem II efficiency and carbon fixation in the marine diatom Thalassiosira pseudonana (3H). Photosyn. Res. 68, 181-92.

Hagen C., Siegmund S. \& Braune W. (2002) Ultrastructural and chemical changes in the cell wall of Haematococcus pluvialis (Volvocales, Chlorophyta) during aplanospore formation. Eur. F. Phycol. 37, 217-26.

Herman J. R., Bhartia P. K., Ziemke J., Ahmad Z. \& Larko D. (1996) UV-B increases (1979-92) from decreases in total ozone. Geophys. Res. Lett. 23, 2117-20.

Huovinen P. S., Oikari A. O. J., Soimasuo M. R. \& Cherr G. N. (2000) Impact of UV radiation on the early development of the giant kelp (Macrocystis pyrifera) gametophytes. Photochem. Photobiol. 72, 308-13.

Jassby A. D. \& Platt T. (1976) Mathematical formulation of the relationship between photosynthesis and light for phytoplankton. Limnol. Oceanogr. 21, 540-7.

Klöser H., Quartino M. L. \& Wiencke C. (1996) Distribution of macroalgae and macroalgal communities in gradients of physical conditions in Potter Cove, King George Island, Antarctica. Hydrobiologia 333, 1-17.

Meador J., Jeffrey W. H., Kase J. P., Pakulski J. D., Chiarello S. \& Mitchell D. L. (2002) Seasonal fluctuation of DNA photodamage in marine plankton assemblages at Palmer Station, Antartica. Photochem. Photobiol. 75, 266-71.

Moe R. L. \& Henry E. C. (1982) Reproduction and early development of Ascoseira mirabilis Skottsberg (Phaeophyta), with notes on Ascoseirales Petrov. Phycologia 21, 55-66.

Morrill L. C. \& Loeblich A. R. III. (1981) The dinoflagellate pellicular wall layer and its occurrence in the division Pyrrhophyta. F. Phycol. 17, 315-23.

Müller D. G., Westermeier R., Peters A. \& Boland W. (1990) Sexual reproduction of the Antarctic brown alga Ascoseira mirabilis (Ascoseirales, Phaeophyceae). Bot. Mar. 33, 251-5.

Nunez M., Davidson A. T. \& Michael K. (2006) Modelled effects of ambient UV radiation on a natural Antarctic marine microbial community. Aquat. Microbial Ecol. 42, 75-90.

Ohnishi N., Allakhverdiev S. I., Takahashi S. et al. (2005) Two-step mechanism of photodamage to photosystem II: step 1 occurs at the oxygen-evolving complex and step 2 occurs at the photochemical reaction center. Biochemistry 44, 8494-9.
Peck L. S., Convey P. \& Barnes D. K. A. (2006) Environmental constraints on life histories in Antarctic ecosystems: tempos, timings and predictability. Biol. Rev. 81, 75-109.

Quartino M. L., Zaixso H. E. \& Boraso de Zaixso A. L. (2005) Biological and environmental characterization of marine macroalgal assemblages in Potter Cove, South Shetland Islands, Antarctica. Bot. Mar. 48, 187-97.

Raven J. A., Johnston A. M., Kübler J. E. et al. (2002) Seaweeds in cold seas: evolution and carbon acquisition. Ann. Bot. 90, 525-36.

Richter M., Rühle W. \& Wild A. (1990) Studies on the mechanism of Photosystem II photoinhibition I. A twostep degradation of D1-protein. Photosynth. Res. 24, 229-35.

Rijstenbil J. W., Coelho S. M. \& Eijsackers M. (2000) A method for the assessment of light-induced oxidative stress in embryos of fucoid algae via confocal laserscan microscopy. Mar. Biol. 137, 763-74.

Roleda M. Y., van de Poll W. H., Hanelt D. \& Wiencke C. (2004) PAR and UVBR effects on photosynthesis, viability, growth and DNA in different life stages of two coexisting Gigartinales: implications for recruitment and zonation pattern. Mar. Ecol. Prog. Ser. 281, 37-50.

Roleda M. Y., Wiencke C., Hanelt D., van de Poll W. H. \& Gruber A. (2005) Sensitivity of Laminariales zoospores from Helgoland to ultraviolet and photosynthetically active radiation: implication for depth distribution and seasonal reproduction. Plant Cell Environ. 28, 466-79.

Roleda M. Y., Hanelt D. \& Wiencke C. (2006a) Exposure to ultraviolet radiation delays photosynthetic recovery in Arctic kelp zoospores. Photosynth. Res. 88, 311-22.

Roleda M. Y., Wiencke C. \& Lüder U. H. (2006b) Impact of ultraviolet radiation on cell structure, UV-absorbing compounds, photosynthesis, DNA damage and germination in zoospores of Arctic Saccorhiza dermatodea. F. Exp. Bot. 57, 3847-56

Roleda M. Y., Clayton M. N. \& Wiencke C. (2006c) Screening capacity of UV-absorbing compounds in spores of Arctic Laminariales. F. Exp. Mar. Biol. Ecol. 338, 123-33.

Roy S. (2000) Strategies for the minimisation of UV-induced damage. In: The Effects of UV Radiation in the Marine Environment (eds S. de Mora, S. Demers \& M. Vernet) pp. 177-205. Cambridge University Press, Cambridge.

Rozema J., van de Staaij J., Björn L. O. \& Caldwell M. (1997) UV-B as an environmental factot in plant life: stress and regulation. Trends Ecol. Evol. 12, 22-8.

Schoenwaelder M. E. A. \& Clayton M. N. (1999) The presence of phenolic compounds in isolated cell walls of brown algae. Phycologia 38, 161-6.

Turcsányi E. \& Vass I. (2002) Effect of UV-A radiation on photosynthetic electron transport. Acta Biol. Szeged. 46, 171-3.

van de Poll W. H., Hanelt D., Hoyer K., Buma A. G. J. \& Breeman A. M. (2002) Ultraviolet-B induced cyclobutanepyrimidine dimer formation and repair in Arctic marine macrophytes. Photochem. Photobiol. 76, 493-501.

Vincent W. F. \& Neale P. J. (2000) Mechanisms of UV damage to aquatic organisms. In: The Effects of UV Radiation in the Marine Environment (eds S. de Mora, S. Demers \& M. Vernet) pp. 149-76. Cambridge University Press, Cambridge.

Wiencke C. (1996) Recent advances in the investigation of Antarctic macroalgae. Polar Biol. 16, 231-40. 
Wiencke C., Clayton M. N. \& Schoenwaelder M. E. A. (2004) Sensitivity and acclimation to UV radiation of zoospores from five species of Laminariales from the Arctic. Mar. Biol. $145,31-9$.

Wiencke C., Clayton M. N., Gómez I. et al. (2007) Life strategy, ecophysiology and ecology of seaweeds in polar polar waters. Rev. Environ. Sci. Biotechnol. 6, 95-126. DOI 10.1007/s11157-006-0001-4.

Wiencke C., Roleda M. Y., Gruber A., Clayton M. N. \& Bischof K. (2006) Susceptibility of zoospores to UV radiation determines upper depth distribution limit of Arctic kelps: evidence through field experiments. F. Ecol. 94, 455-63. 